\title{
Morphology and DNA content of bacterioplankton in the northern Gulf of Mexico: analysis by epifluorescence microscopy and flow cytometry
}

\author{
Frank J. Jochem* \\ The University of Texas at Austin, Marine Science Institute, 750 Channel View Drive, Port Aransas, Texas 78373, USA
}

\begin{abstract}
The distribution of pelagic bacteria was assessed along 2 offshore - onshore transects in the northwestern Gulf of Mexico in July and October 1999 and along a salinity gradient (0.2 to $34.4 \%$ ) in the Mississippi River plume in May 2000. Cell abundance was estimated by epifluorescence microscopy after DAPI staining and by flow cytometry after DNA staining with SYBR Green I. Total bacterial counts by both techniques corresponded well. Bacterial abundance ranged from $0.9 \times$ $10^{6}$ to $1.35 \times 10^{6}$ cells $\mathrm{ml}^{-1}$ in the upper $200 \mathrm{~m}$ of the water column in the northwestern Gulf and from $0.1 \times 10^{6}$ to $2.05 \times 10^{6}$ cells ml $^{-1}$ in the Mississippi River plume. Bacteria exhibited surface maxima in July 1999 but subsurface maxima in the upper half of the chlorophyll maximum in October 1999 and off the Louisiana shelf break in May 2000. Stations with a thin layer of low-salinity plume water exhibited an additional bacterial maximum at the surface. Within the Mississippi River plume, bacterial abundance decreased with increasing salinity, and their maximum abundance preceded the chlorophyll maximum along the salinity gradient. Three morphotypes of bacteria were distinguished by epifluorescence microscopy: cocci, rod-shaped bacteria, and curved bacteria. Cocci (40 to $60 \%$ of total bacteria; counts corrected for Prochlorococcus spp.) were the most common morphotype. Rods and curved bacteria had similar shares (18 to $25 \%$ ) and presented multi-species consortia as indicated by the variability in size and shape of cells within each group. Flow cytometry revealed 4 bacterial subpopulations distinguished by their DNA content, none of which seem to reflect a specific morphotype. Whereas regional differences in the contribution of the distinguished DNA types to total bacterial abundance were low in the open Gulf, a switch in predominance from low-DNA to highDNA cells below the subsurface chlorophyll maximum was obvious in all profiles. The ecological significance of bacterial DNA types as revealed by flow cytometry is discussed in the context of published results.
\end{abstract}

KEY WORDS: Gulf of Mexico $\cdot$ Mississippi River plume $\cdot$ Bacterial abundance $\cdot$ Morphology $\cdot$ DNA content $\cdot$ Flow cytometry

Resale or republication not permitted without written consent of the publisher

\section{INTRODUCTION}

The prokaryotic fraction of marine planktonic communities consists of both phototrophic and heterotrophic organisms. Phototrophic prokaryotes often dominate phytoplankton in oligotrophic waters (Campbell et al. 1994, Jochem 1995) and contribute a large per-

${ }^{*}$ Present address: Florida International University, 3000 NE 151 St, North Miami, Florida 33181, USA.

E-mail: frank@jochem.net centage of primary production (Jochem et al. 1993, Jochem \& Zeitzschel 1993, Li 1994). Heterotrophic bacteria constitute an important share of total plankton biomass similar to or higher than that of primary producers, and play a significant role in pelagic heterotrophic processes (Cho \& Azam 1990). They generally dominate the 0.2 to $2.0 \mu \mathrm{m}$ size class of marine plankton in terms of abundance and biomass (Campbell et al. 1994).

Most estimates of bacterial abundance and biomass have relied on epifluorescence microscopy counts after 
DNA staining and filtration onto Nuclepore filters. Because of its time-consuming nature, this technique does not lend itself to large-scale field studies, which generate numerous samples, and often lacks precision because only a relatively modest number of cells can be counted (Venrick 1978). Whereas the coccoid cyanobacteria Synechococcus spp. are well separated from bacteria by their orange autofluorescence, epifluorescence microscopy is not sensitive enough to discriminate Prochlorococcus spp. from heterotrophic bacteria, which can cause a significant overestimation of bacterial abundance (Campbell et al. 1994, Sieracki et al. 1995). The application of flow cytometry to aquatic microbial ecology and the recent development of blue-light excited cyanine dyes (Lebaron et al. 1998) helped to establish new protocols for cytometric quantification of heterotrophic bacteria, which turned out to be much faster and more precise than traditional microscopic methods (see review in Gasol \& del Giorgio 2000). Phototrophic prokaryotes, Prochlorococcus spp. and Synechococcus spp., can be distinguished from heterotrophic bacteria by their chlorophyll autofluorescence in cytometric analyses ( $\mathrm{Li}$ et al. 1995, Marie et al. 1997, Gasol \& del Giorgio 2000).

Besides establishing the abundance and importance of bacteria, microbial ecologists are now addressing bacterioplankton diversity. Information on bacterioplankton diversity has long been scarce and could be addressed only recently by new molecular tools. Despite significant progress in molecular biology, most of these techniques are still in their developmental phase, sometimes difficult to quantify and too laborious for application in extended field surveys (Collier \& Campbell 1999). DNA staining in combination with flow cytometry has now been introduced to differentiate and quantify subpopulations of bacteria with different apparent DNA content and to reveal their distribution patterns and ecological significance (Li et al. 1995, Marie et al. 1997, Gasol et al. 1999, Casotti et al. 2000).

The aim of the present study was to establish regional and vertical distribution patterns of heterotrophic bacteria in the open northern Gulf of Mexico and the Mississippi River plume by epifluorescence microscopy and flow cytometry. Knowledge of bacterioplankton in the open Gulf of Mexico is scarce (Biddanda \& Benner 1997) because most studies concentrated on the Mississippi River plume and Louisiana shelf waters (Chin-Leo \& Benner 1992, Amon \& Benner 1998, Pakulski et al. 2000). Vertical and regional patterns in bacterioplankton diversity were addressed by quantification of morphologically distinguished bacteria using epifluorescence microscopy and of subpopulations with different apparent DNA content using flow cytometry. Previous studies on the apparent DNA content of heterotrophic bacteria led to the hypothesis that low-DNA bacteria are dormant or inactive and only high-DNA bacteria are active (reviewed in Gasol \& del Giorgio 2000). The present study aimed to reveal natural distribution patterns of low- versus high-DNA bacteria in the oligotrophic open Gulf of Mexico and the eutrophic Mississippi River plume.

\section{MATERIALS AND METHODS}

Samples for bacterial counts were taken by CTDmounted Niskin-type water bottles from 8 to 10 depths in the upper $200 \mathrm{~m}$ water column at 6 stations during July 21 to 24, 1999 (Stn J1 to J6) and 5 stations during October 21 to 25, 1999 (Stn O1 to O5) in the northwestern Gulf of Mexico (Fig. 1a). Following a salinity gradient from 0.2 to $34.4 \%$, 9 stations were sampled in the Mississippi River plume and off the Louisiana shelf break during May 19 to 29, 2000 (Fig. 1b); stations off the shelf break comprised 10 depths in the upper $200 \mathrm{~m}$ water column, sampled at Stn 5, a total of 10 depths down to the bottom at $46 \mathrm{~m}$, and river mouth stations only surface samples.

Temperature and salinity were recorded by a SeaBird 911-Plus CTD equipped with a Sea Tec FL0500 fluorometer (Sea-Bird Electronics Inc., Bellevue, WA) for in situ chlorophyll fluorescence analysis. Nutrients (nitrate, nitrite, ammonia) were analyzed in the laboratory on deep-frozen water samples on a Lachat QuickChem autoanalyzer (Lachat Instruments, Milwaukee, WI). Plankton samples were fixed by $1 \%$ (final conc.) formaldehyde and stored at $4{ }^{\circ} \mathrm{C}$ in the dark until analyses. For epifluorescence microscopy, 0.5 to $1 \mathrm{ml}$ of sample was diluted with $0.2 \mu \mathrm{m}$ filtered seawater to a final volume of $5 \mathrm{ml}$, incubated with DAPI ( $1 \mathrm{mg} \mathrm{l}^{-1}$ final conc.) for $5 \mathrm{~min}$ and filtered onto black $0.2 \mu \mathrm{m}$ Nuclepore filters (Osmonics Laboratory Products Group, Minnetonka, MN), which were supported by $0.2 \mu \mathrm{m}$ mixed ester membrane filters to help distribute the cells homogeneously. Filters were stored frozen until samples were counted under UV excitation on a Zeiss Axioskop microscope (Carl Zeiss, Oberkochen, Germany). Depending on abundance, 200 to 500 cells were counted on 60 to 200 view fields. Bacteria were differentiated into morphotypes of cocci (spherical cells), rods (elongated cells) and curved bacteria (C-shaped and S-shaped cells). Cell counts of coccoid bacteria were corrected for prochlorophyte abundance derived from flow cytometry analyses of unstained samples. Prochlorophytes would also be counted as coccoid bacteria on DAPI-stained filters and can over-estimate bacterial abundance (Sieracki et al. 1995). For occasional estimates of bacterial cell size, digital images were taken by a Nikon Coolpix 900 camera (Nikon Corp., Tokyo, Japan) and analyzed by UTHSCSA ImageTool 

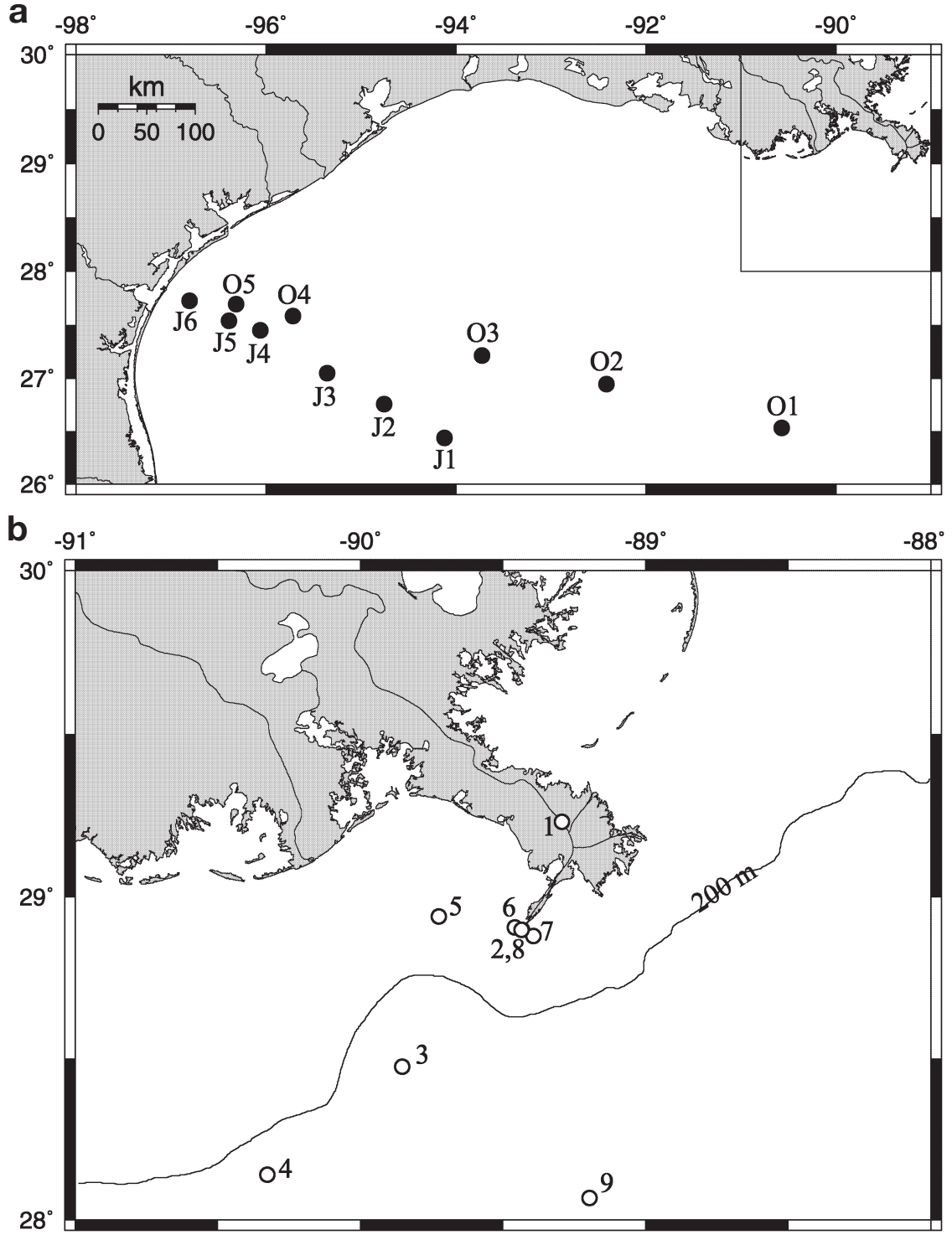

Fig. 1. Location of sampling stations (a) in the northwestern Gulf of Mexico during cruises in July (J1 to J6) and October (O1 to O5) 1999, mapped from South Texas to Louisiana; and (b) along the Mississippi River plume off Louisiana in May 2000 (map corresponds to marked section in [a])

ver. 2.0 (The University of Texas Health Science Center, San Antonio, TX) calibrated with $0.993 \mu \mathrm{m}$ reference beads (Polysciences, Inc., Warrington, PA).

For flow cytometry counts of heterotrophic bacteria, $1 \mathrm{ml}$ of fixed sample was incubated for $30 \mathrm{~min}$ at $37^{\circ} \mathrm{C}$ with $0.1 \mathrm{~g} \mathrm{l}^{-1}$ RNAse (1:1 mix of RNAse A and B) before staining with SYBR Green I $\left(10^{-5}\right.$ dilution of commercial stock; Molecular Probes, Eugene, OR) in the presence of $30 \mathrm{mM}$ potassium citrate (Marie et al. 1997). After 20 min of staining, samples were analyzed on a Becton-Dickinson (San José, CA) FACSort flow cytometer with a flow rate of $0.2 \mu \mathrm{l} \mathrm{s}^{-1}$. The counting rate was kept $<500$ cells s$^{-1}$; too dense samples were diluted 1:10 with $0.2 \mu \mathrm{m}$ filtered seawater. The measured sample volume for estimates of bacteria $\mathrm{ml}^{-1}$ was calculated from measurement times (60 to $300 \mathrm{~s}$ ) based on weight calibration of flow rates.

Because of its broad emission spectrum, SYBR DNA fluorescence was detected in both the green FL1 (535 \pm $15 \mathrm{~nm}$ ) and the red FL3 (>650 nm) fluorescence channels. Side-Angle Light Scatter (SSC) served as a proxy for bacterial cell size (Troussellier et al. 1999). All signals were recorded on a 4 -decades log scale. Data were analyzed by PC Lysys software (BectonDickinson). DNA clusters of heterotrophic bacteria were counted by logical gating from both FL1 vs Fl3 and SSC vs FL1 histograms, with gate borders set at the minima in frequency distributions of DNA fluorescence and light scatter. Regions for gating were adjusted to each measurement to meet the minimum in frequency distribution criteria. In near-surface samples, where prochlorophytes and bacteria were not separated in the cytometric analyses, bacterial measurements were corrected for prochlorophyte counts from unstained, fixed samples measured on the same day; prochlorophyte abundance was subtracted from cluster B-III including the prochlorophytes after DNA staining. Cluster B-IV not only was separated from B-III by apparent DNA fluorescence but took the higher light scatter of B-IV into account as well. For October 1999 and May 2000 samples, all cytometric analyses were performed in triplicate and data are presented as means. For occasional cell sorting (B-Ia, B-IV), cells from the inner $2 / 3$ of the counting gates were sorted by the exclusion mode at a rate of $<300 \mathrm{~s}^{-1}$ into $0.2 \mu \mathrm{m}$ filtered seawater. Sorted cells were filtered, stained with DAPI and measured under the epifluorescence microscope as described above.

\section{RESULTS}

All samples contained the 3 distinguished morphotypes of bacteria. Coccoid bacteria averaged $0.42 \mu \mathrm{m}$ in diameter $\left(0.04 \mu^{3}\right.$ cell volume) but comprised both 
smaller $\left(0.26\right.$ to $\left.0.33 \mu \mathrm{m}_{i} 0.014 \mu \mathrm{m}^{3}\right)$ and larger ( 0.40 to $0.55 \mu \mathrm{m} ; 0.06 \mathrm{\mu m}^{3}$ ) forms. Most rod-shaped bacteria were about 0.5 to $0.6 \times 0.13$ to $0.2 \mu \mathrm{m}$ in size $\left(0.01 \mu \mathrm{m}^{3}\right)$. However, both smaller $(0.3$ to $0.35 \times 0.15 \mu \mathrm{m}$; $\left.0.005 \mu \mathrm{m}^{3}\right)$ and larger $(0.7$ to $1.3 \times 0.3$ to $0.4 \mu \mathrm{m}$; $0.09 \mathrm{\mu m}^{3}$ ) cells occurred in smaller numbers. Among curved bacteria, small C-formed cells $(0.5$ to $0.7 \mu \mathrm{m}$ length measured straight from tip to tip, 0.15 to

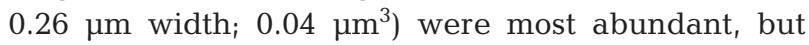
some samples contained a substantial fraction of smaller C-forms $\left(0.3 \times 0.12 \mu \mathrm{m}_{;} 0.01 \mu \mathrm{m}^{3}\right)$. Large C-formed (0.9 to $1.5 \mu \mathrm{m}$ length, 0.3 to $0.4 \mu \mathrm{m}$ width; $\left.0.26 \mu^{3}\right)$ and 2 large S-formed cells $(0.8 \times 0.2 \mu \mathrm{m}$,

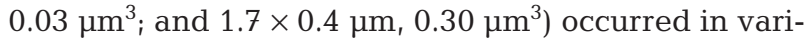
able but low numbers. For statistically significant cell counts, all variations of $\mathrm{C}$ - and S-shaped cells were cumulated as 'curved bacteria', as were all types of rod-shaped and coccoid bacteria.

Four clusters of bacteria, present in all samples except in those from Stn 1 of the May 2000 cruise in the Mississippi River $(0.2 \%)$, could be distinguished by DNA content in cytometric analyses (Figs $2 \& 3$ ). Clusters B-Ia and B-Ib probably correspond to B-I bacteria as identified cytometrically and termed by $\mathrm{Li}$ et al. (1995) and Marie et al. (1997) in samples from the North Atlantic, the Mediterranean and the English Channel. Cluster B-III corresponds to B-III of Marie et al. (1997), which was not detected by Li et al. (1995). A cluster termed B-II by Li et al. (1995) and Marie et al. (1997), distinguished by higher DNA content but lower light scatter than that of B-I, was not detected. Instead, a high DNA content and light scatter cluster, indicating larger cell size (B-IV), occurred. In Mississippi River water (Stn 1, 0.2\%), only 2 clusters (high and low apparent DNA content) with similar light scatter signatures could be distinguished (not shown), which could not be related to any of the 4 bacteria clusters recorded in marine samples.

Counts of total heterotrophic bacteria by microscopy and flow cytometry showed statistically significant $(\mathrm{p}<0.001)$ linear relations (Fig. 4). In October 1999 and May 2000, microscopic and cytometric analyses were performed immediately after the cruise, and the relation between both estimates of total bacteria is close to $1: 1(1.038 \pm 0.023$ and $1.187 \pm 0.022$, respectively; both not statistically significant different from $1, t$-test, $\mathrm{p}<0.001$ ). For the July 1999 cruise, cytometric analyses were performed 2.5 mo later than preparation of Nuclepore filter slides used for epifluorescence microscopy. Recovery of total bacteria by cytometry was $75 \%$ (slope of $0.746 \pm 0.019$ ) compared with microscopy, which compares with the reported loss of bacteria cells in $4^{\circ} \mathrm{C}$-stored, formalin-fixed samples over storage time (Turley \& Hughes 1992, Troussellier et al. 1995).
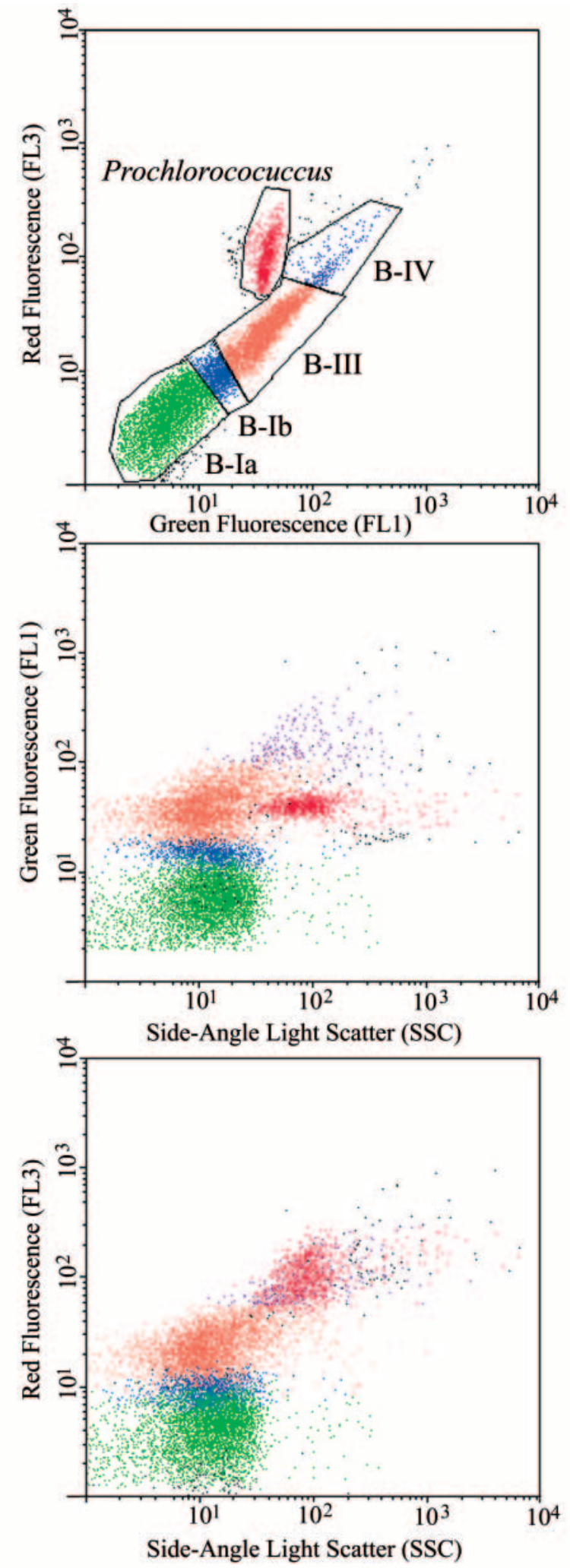

Fig 2. Cytometric 2-parameter plots reveal 4 types of bacteria distinguished by their DNA content. Prochlorococcus spp. are separated from heterotrophic bacteria in green versus red fluorescence plots. Cell types named after previously published results (see text). Stn O1, October 1999, 70 m 


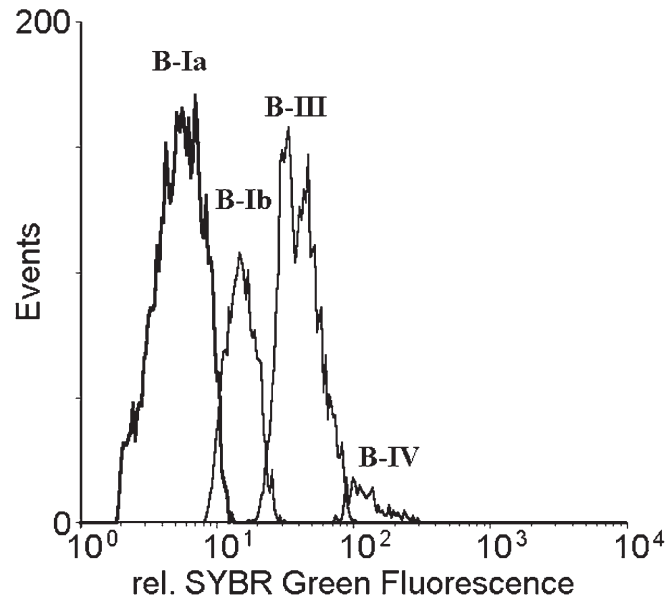

Fig. 3. Frequency distribution of apparent DNA fluorescence (relative units of SYBR Green fluorescence cell ${ }^{-1}$ ) for the 4 distinguished bacteria DNA clusters. Cell types named after previously published results (see text). Station O1, October $1999,70 \mathrm{~m}$

None of the cytometrically established DNA types of bacteria co-varied significantly with any microscopically identified morphotype. In fact, microscopic inspection of occasionally flow-sorted DNA type subpopulations revealed that, for example, B-IV comprised mainly elongated, faintly stained rods of variable cell length, and a small amount of large C- and S-formed bacteria, but also small, very brightly stained coccoid cells. These bright coccoid cells were about twice as big as the small cocci that contributed the vast majority of B-Ia, but both were recorded as coccoid bacteria in microscopic counts.

In July 1999, bacteria exhibited surface maxima of abundance, ranging from $\sim 0.4 \times 10^{6}$ cells ml-1 offshore to $\sim 1.0 \times 10^{6}$ cells $\mathrm{ml}^{-1}$ inshore (Fig. 5). Only the shallow $(60 \mathrm{~m})$ shelf Stn 6 showed a near-bottom maximum of $1.35 \times 10^{6}$ cells $\mathrm{ml}^{-1}$. In October 1999, subsurface maxima of 0.3 to $0.4 \times 10^{6}$ cells ml ${ }^{-1}$ occurred within the chlorophyll maximum, and abundance did not increase toward the shelf as recorded in July (Fig. 6). Cocci were the most abundant morphotype of bacteria, but more dominant in July (58 $\pm 7 \%$ ) than in October (48 $\pm 6 \%$ ). Rod-shaped and curved bacteria were equally abundant: $18 \pm 4 \%$ and $24 \pm 5 \%$ in July, and $27 \pm 5 \%$ and $25 \pm 5 \%$ in October 1999, respectively. Maximum shares of cocci, and minimum shares of rods and curved bacteria occurred within the lower part of the chlorophyll subsurface maximum (Figs $5 \& 6$ ). B-Ia and B-III were the most abundant DNA types of bacteria during both cruises (Figs $5 \& 6$ ). B-Ia dominated the upper water column down to the bottom of the chlorophyll subsurface maximum (40 to $60 \%$ ), whereas B-III dominated below the euphotic zone (40 to $55 \%$ ). B-Ib followed the vertical distribution of B-Ia, whereas the larger B-IV bacteria gained a higher share below the euphotic zone. The vertical pattern of DNA types was consistent among all stations. Bacterial abundance integrated over $200 \mathrm{~m}$ water depth was higher in July (Fig. 7a, black bars) than in October (Fig. 8a, black bars). Except for the shallow shelf stations, integrated abundance showed minor regional variation. Despite their high cell numbers volume ${ }^{-1}$, the shelf stations
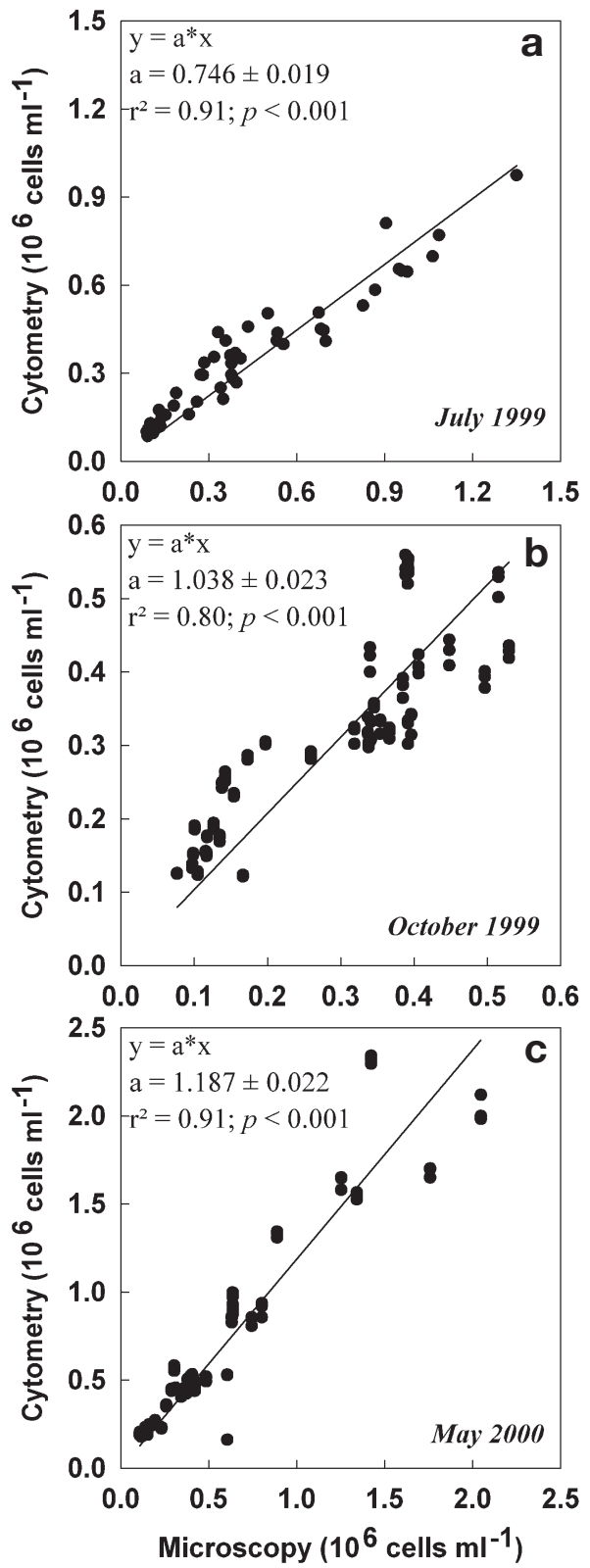

Fig. 4. Relation between total bacterial abundance $\left(10^{6}\right.$ cells $\mathrm{ml}^{-1}$ ) as estimated by epifluorescence microscopy and flow cytometry for cruises in (a) July, (b) October 1999, and (c) May 2000 


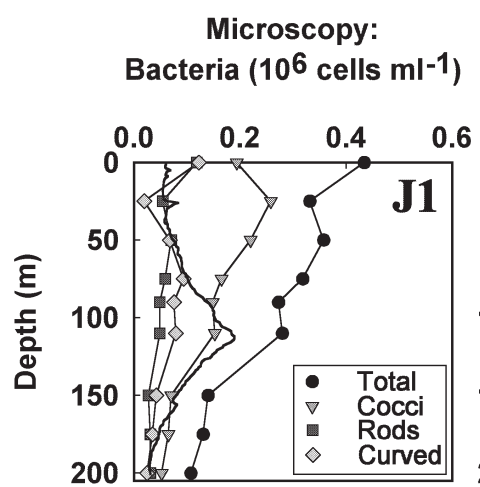

Fraction of
Bacteria Morphotypes (\%)

Cytometry:

Fraction of

Microscopy:
Bacteria (106 cells ml-1)

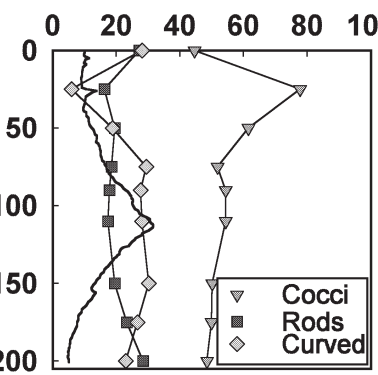

Bacteria $\left(10^{6}\right.$ cells $\left.\mathrm{ml}^{-1}\right)$

Bacteria DNA Types (\%)
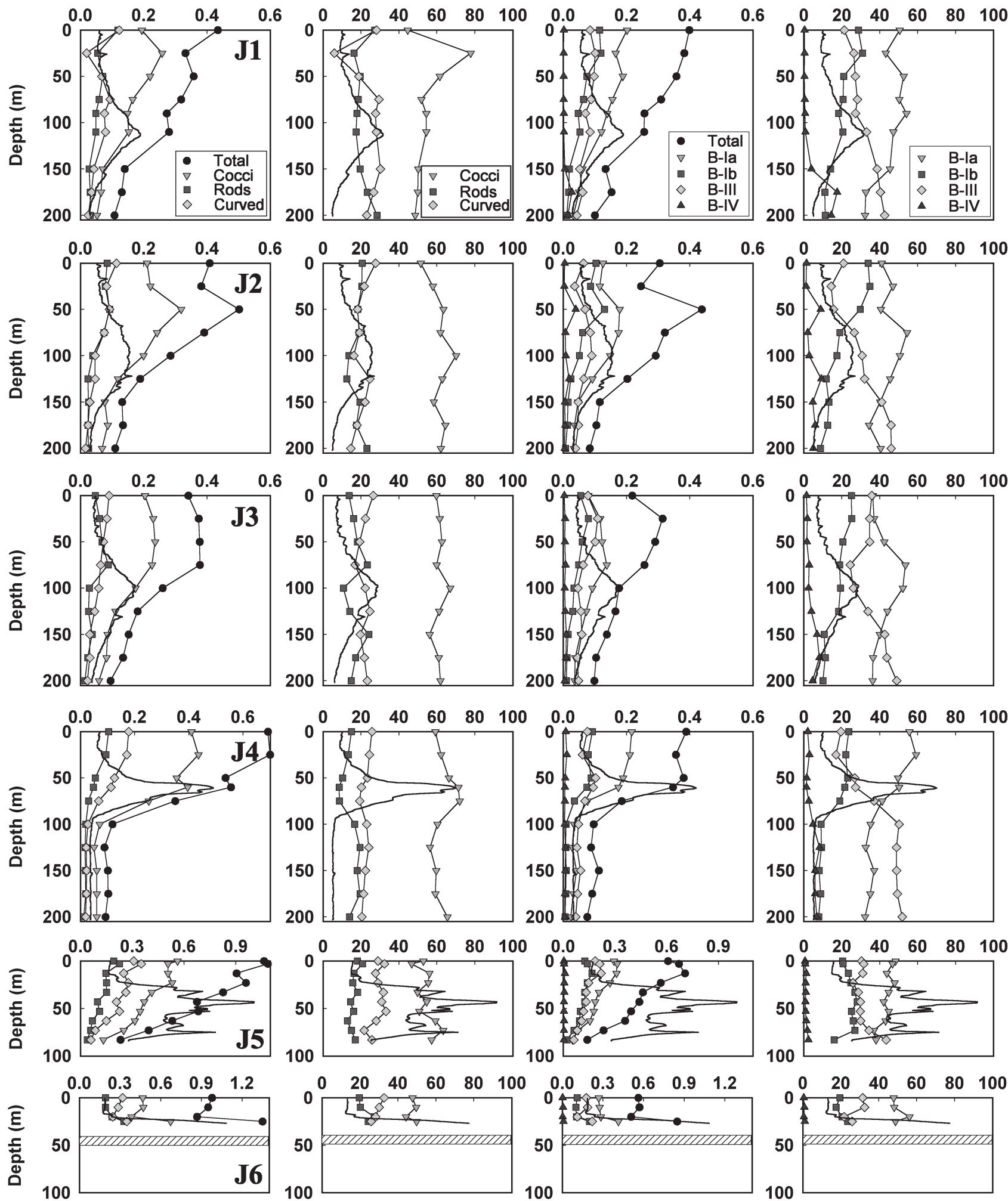

Fig. 5. Profiles of bacterial abundance $\left(10^{6}\right.$ cells $\left.\mathrm{ml}^{-1}\right)$ and the proportion of morpho- and DNA types in the northern Gulf of Mexico, July 1999. Overlaid is the profile of in situ chlorophyll fluorescence (relative units). The hatched bars in the lower panel indicate the sea floor. Station numbers are given in the left panel for each row 
Microscopy:

Fraction of

Cytometry:

Fraction of Bacteria (106 cells ml-1) Bacteria Morphotypes (\%) Bacteria (106 cells ml-1) Bacteria DNA Types (\%)
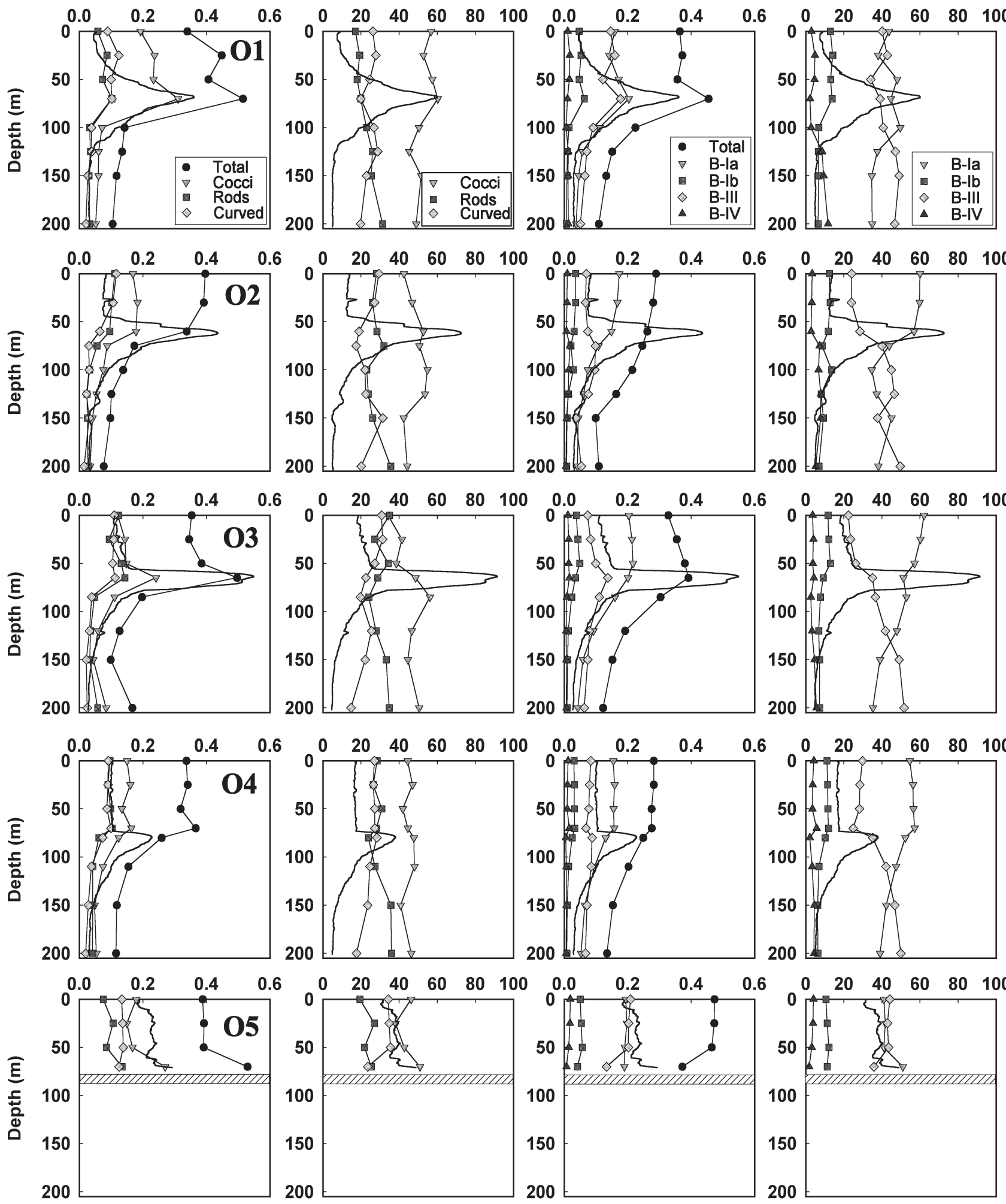

Fig. 6. Profiles of bacterial abundance $\left(10^{6}\right.$ cells $\left.\mathrm{ml}^{-1}\right)$ and the proportion of morpho- and DNA types in the northern Gulf of Mexico, October 1999. Overlaid is the profile of in situ chlorophyll fluorescence (relative units). The hatched bars in the lower panel indicate the sea floor. Station numbers are given in the left panel for each row 

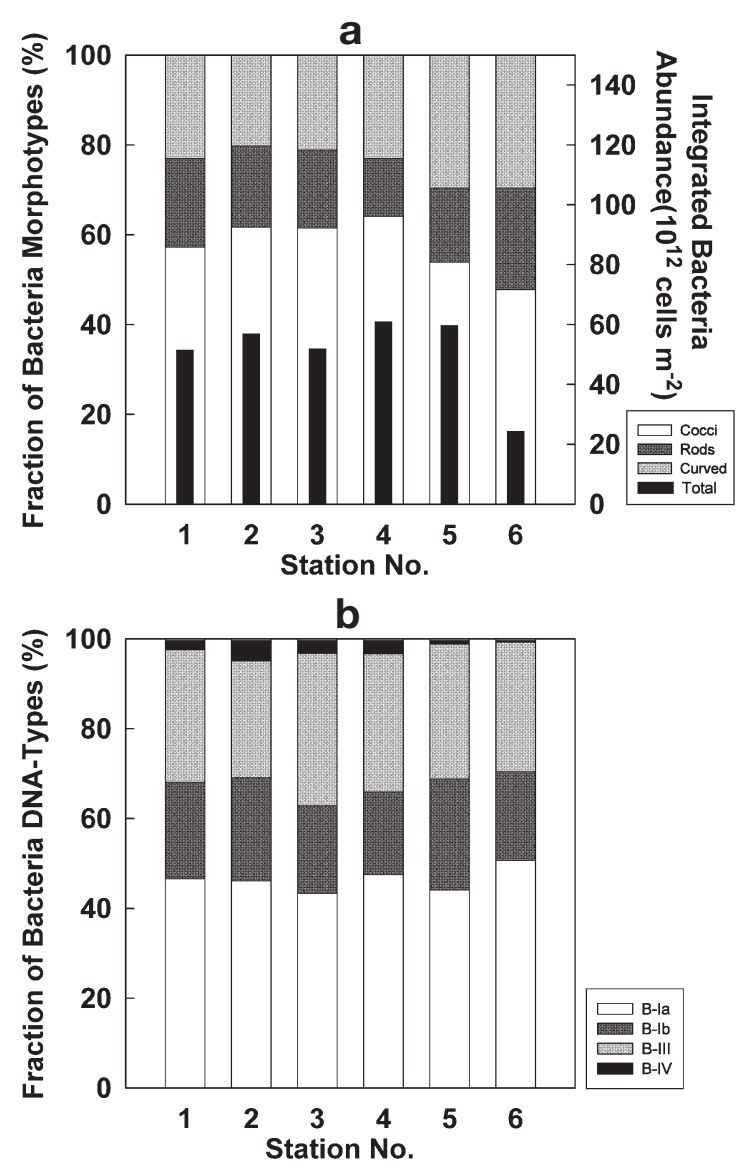

Fig. 7. Integrated bacteria abundance (upper $200 \mathrm{~m}$ water column; $10^{12}$ cells $\mathrm{m}^{-2}$, black bars in upper panel) and proportion of (a) morphotypes and (b) DNA types to total integrated bacterial numbers in the northern Gulf of Mexico, July 1999

exhibited lower integrated abundances due to their shallow depths. Among the morphotypes, the shares of cocci $(57.7 \pm 2.3 \%$ and $47.2 \pm 2.1 \%)$ tended to decrease toward the coast, while those of curved bacteria (24.4 \pm $1.5 \%$ and $26.5 \pm 1.6 \%$ ) tended to increase, for July and October, respectively. Rod-shaped bacteria (17.9 \pm $1.2 \%$ and $26.3 \pm 1.7 \%$ ) lacked a regional trend in their contribution to integrated abundance (Figs $7 \& 8$ ). Among the cytometric DNA types (Figs $7 b$ \& 8b), larger B-IV bacteria $(2.6 \pm 0.6 \%$ and $4.3 \pm 0.4 \%)$ seemed to be more important at offshore stations in July but lacked a trend in October. B-Ia bacteria dominated integrated abundances $(46 \pm 1 \%$ and $47 \pm 2 \%$ ), followed by B-III ( $30 \pm 1 \%$ and $38 \pm 2 \%$ ). B-Ib contributed $21.2 \pm 1 \%$ and $10.6 \pm 0.4 \%$ in July and October, respectively. Despite some variation in the shares of the different DNA types, no regional trend or major variation is discernible. Along the Mississippi River plume (May 2000 cruise), total bacterial abundance in surface samples decreased from $2.0 \times 10^{6} \mathrm{cells} \mathrm{m}^{-1}$ in the lower river $(0.2 \%)$ to $0.4 \times 10^{6} \mathrm{cells} \mathrm{ml}^{-1}$ at offshore stations (>33\%; Fig. 9a). Thereby, bacterioplankton abundance paralleled the decrease in nitrate and ammonia concentrations along the salinity gradient, whereas phytoplankton (in terms of in situ chlorophyll fluorescence) seemed to exhibit highest standing stocks at mid-salinities (10 to $22 \%$; Fig. 9d). Nitrite concentrations of up to $0.78 \mu \mathrm{M}$ also peaked in midsalinity surface waters (Fig. 9d) and showed primary maxima ( 0.4 to $0.7 \mu \mathrm{M}$ ) within the subsurface chlorophyll maxima at the deeper stations (data not shown).

Cocci contributed 40 to $57 \%$ of total bacteria; the share of rod-shaped bacteria decreased from 23 to $28 \%$ to 16 to $19 \%$ along the salinity gradient, whereas the contribution of curved bacteria increased from 15 to $24 \%$ to 38 to $44 \%$ (Fig. 9b). B-Ia DNA type bacteria were the most abundant cluster, contributing 26 to $50 \%$ (mean $41.6 \pm 2.8 \%$ ) to the total bacterioplankton. B-Ib $(22.3 \pm 1.1 \%)$ and B-III (22 to $47 \%$, mean $31.7 \pm$ $3 \%$ ) bacteria showed similar shares, and B-IV bacteria were less important ( 2 to $8 \%$, mean $4.4 \pm 0.7 \%$ ). No
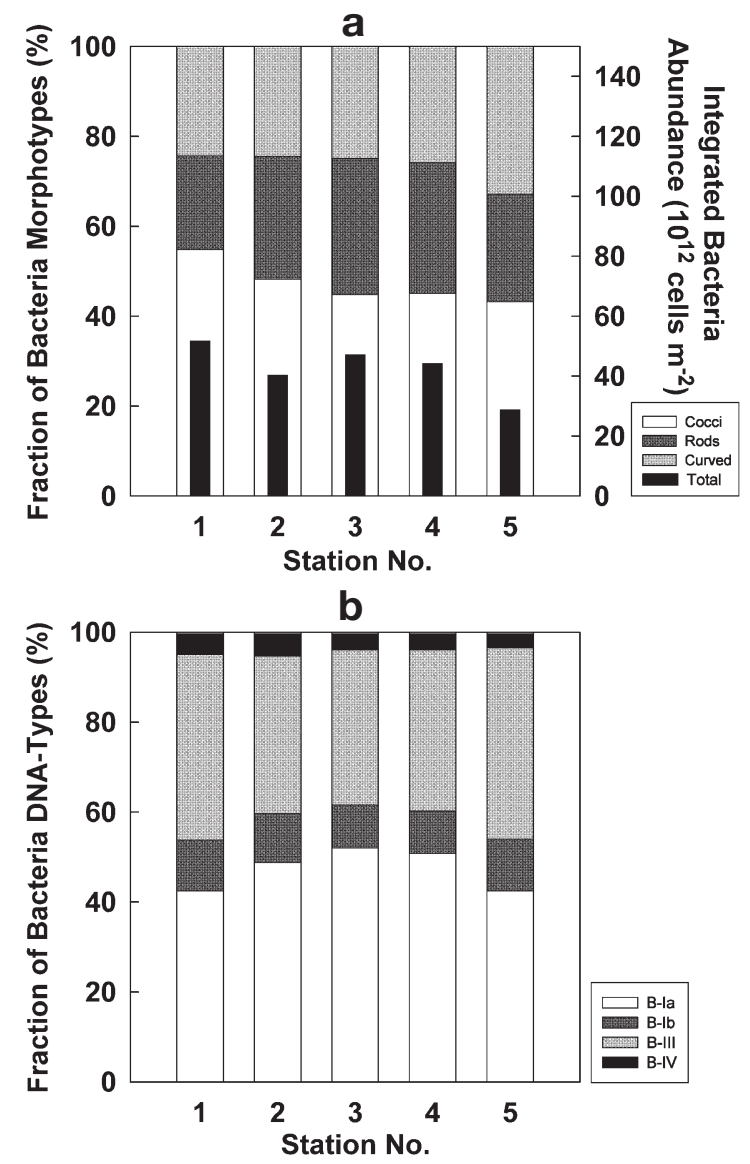

Fig. 8. Integrated bacterial abundance (upper $200 \mathrm{~m}$ water column; $10^{12}$ cells $\mathrm{m}^{-2}$, black bars in upper panel) and proportion of (a) morphotypes and (b) DNA types to total integrated bacterial numbers in the northern Gulf of Mexico, October 1999 

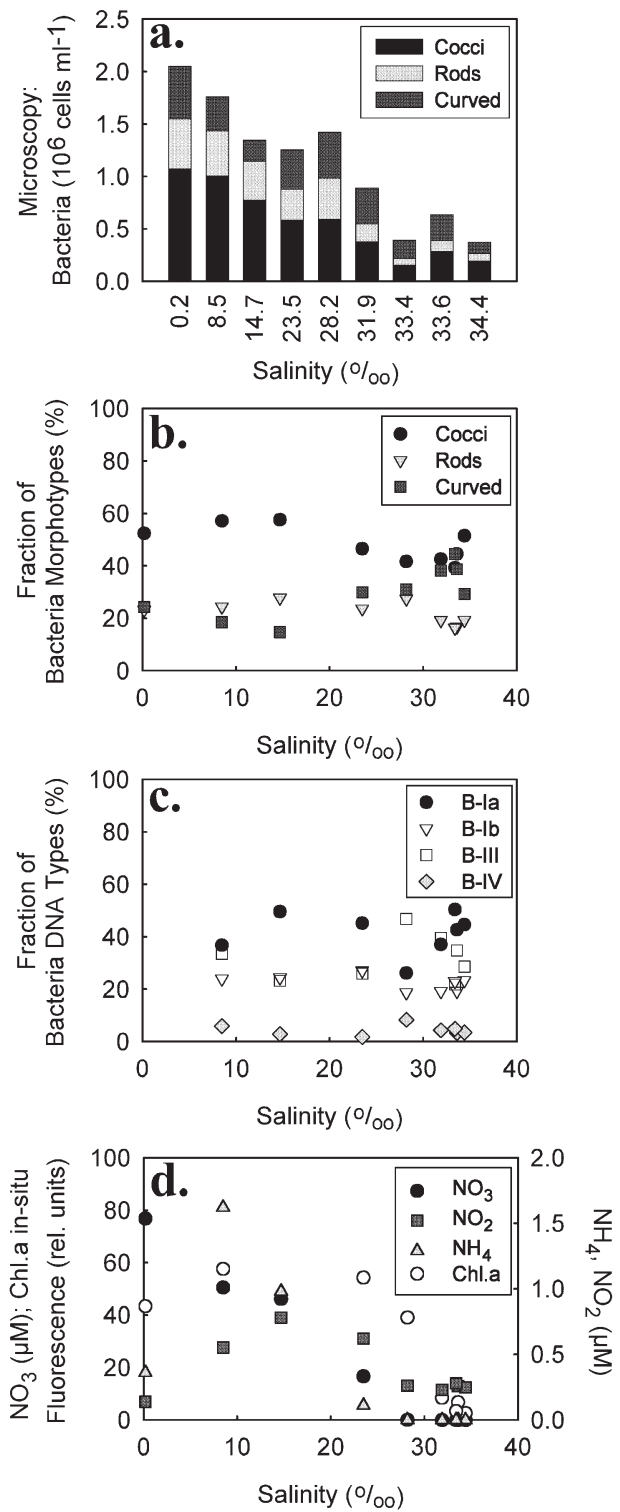

Fig. 9. Distribution and composition of bacterioplankton in surface samples along the salinity gradient in the Mississippi River plume, May 2000. (a) Bacterial abundance $\left(10^{6}\right.$ cells $\mathrm{ml}^{-1}$ ) and composition by morphotypes; (b) proportion of morphotypes to total bacterial numbers; (c) proportion of DNA types to total bacterial numbers; (d) nutrient concentrations $\left(\mathrm{NO}_{3}, \mathrm{NO}_{2}, \mathrm{NH}_{4} ; \mu \mathrm{M}\right)$ and in situ chlorophyll fluorescence (relative units)

regional trend was discernible in the distribution of bacterial DNA clusters (Fig. 9c).

Vertical profiles at the deeper stations revealed bacteria maxima in the upper half of or slightly above the chlorophyll subsurface maximum (Fig. 10). In addition, slim surface layers of river plume water (as seen from salinity profiles, Fig. 10 lower panel) caused a surface maximum at Stns 5 and 3. As in the open northern Gulf of Mexico, cocci were the most abundant morphotypes throughout the water column $(51.4 \pm 6.1 \%)$ with decreased shares at the surface. Curved bacteria $(28.7 \pm$ $6.1 \%)$ were more abundant than rods $(19.8 \pm 5.1 \%)$, as was found in the northern Gulf in October 1999, but the share of rods increased below $150 \mathrm{~m}$. The vertical distribution of bacterial DNA types (Fig. 10) corresponds to those of the northern Gulf cruises. B-Ia ( $41 \pm$ $0.6 \%)$ and B-III $(34.8 \pm 0.6 \%)$ were the most abundant DNA types with B-Ia dominating in the upper water column and B-III below the chlorophyll subsurface maximum. Shares of B-Ib $(19 \pm 0.3 \%)$ were quite constant throughout the water column except for a decrease below the chlorophyll subsurface maximum at Stn 9. B-IV shares $(5.2 \pm 0.3 \%)$ generally increased below the subsurface maximum.

\section{DISCUSSION}

Although the preference for any of the recently marketed suite of blue-excitable cyanine dyes remains a personal choice of each investigator (Gasol \& del Giorgio 2000), SYBR Green I exhibits the highest quantum yield and cellular DNA fluorescence (Lebaron et al. 1998). It is less dependent on the ionic strength of the medium and is therefore best suited for work in seawater (Lebaron et al. 1998), and its fluorescence is high enough to allow even microscopic counting of viruses (Noble \& Fuhrman 1998). In contrast to SYBR Green (Marie et al. 1997), YoYo-1 stained samples can be stored in the dark without significant loss of DNA fluorescence; however, it requires a much longer staining (Jochem \& Meyerdierks 1999). The best choice of dye, thus, might depend on the specific needs (fast staining versus storage, single or dual labeling, average DNA content of investigated cells and instrument sensitivity) of each investigation.

Bacterial counts by epifluorescence microscopy and flow cytometry from the October 1999 and May 2000 cruises showed significant correlations with a slope not significantly different from 1 , which confirms previous comparisons between the 2 methods using different DNA dyes (Li et al. 1995, Lebaron et al. 1998, Troussellier et al. 1999). Slopes slightly above 1.0 in cytometry versus microscopy comparisons, which were also found in earlier studies (Lebaron et al. 1998, Gasol et al. 1999), were explained by underestimation of bacterial abundance by microscopy since 2 to $6 \%$ of small bacterial cells were found to pass through $0.2 \mu \mathrm{m}$ Nuclepore filter membranes (Gasol \& Morán 1999). The roughly $25 \%$ loss of bacterial cells in fixed samples stored at $4^{\circ} \mathrm{C}$ for 2.5 mo before they were analyzed cytometrically (July 1999 cruise) points toward storage concerns as reported previously (Turley \& Hughes 1992, Troussellier et al. 1995). The significant linear 


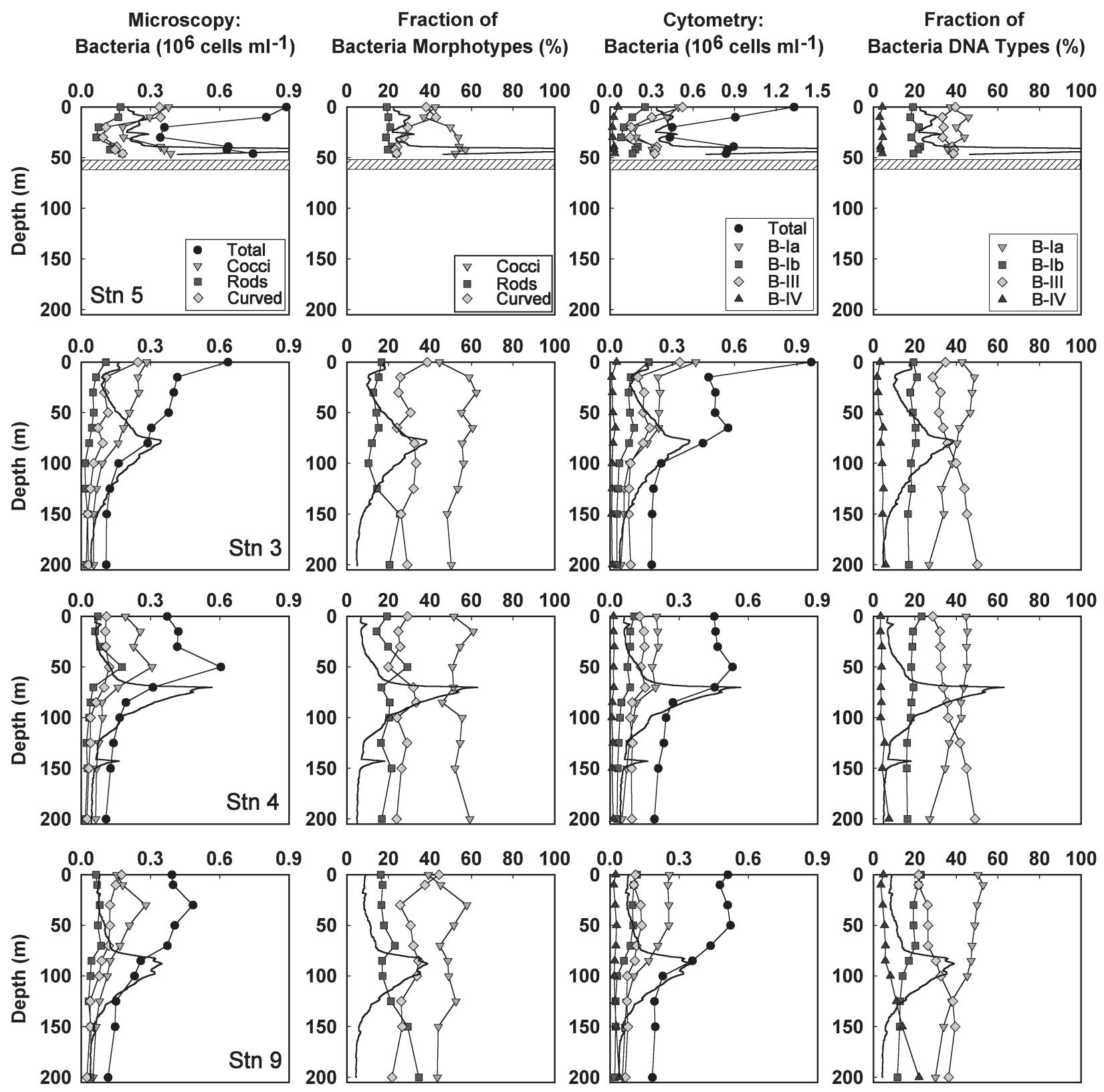

Salinity $(\%)$; Chlorophyll in-situ fluorescence (rel. units)

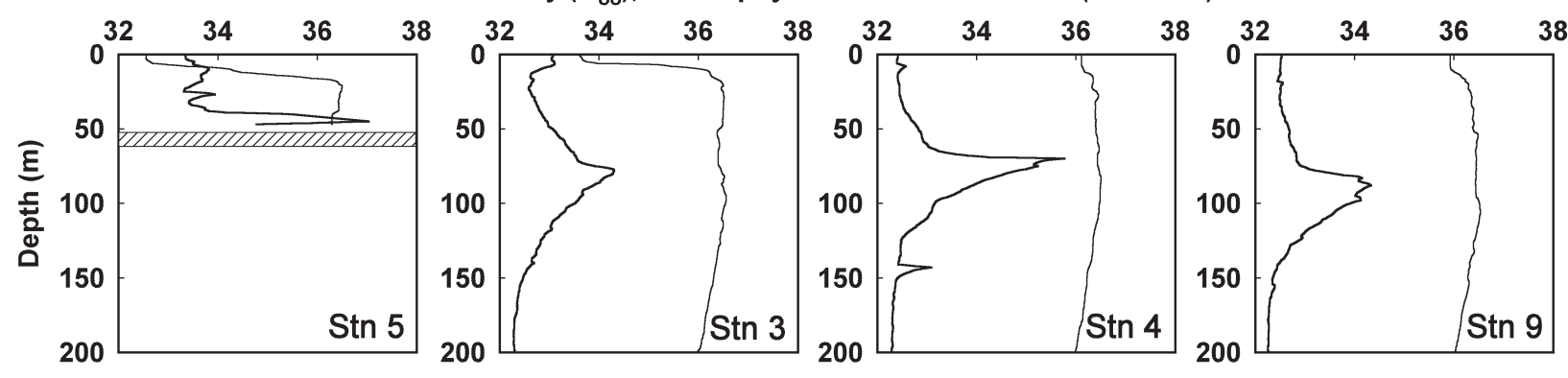

Fig. 10. Profiles of bacterial abundance $\left(10^{6}\right.$ cells $\left.\mathrm{ml}^{-1}\right)$ and the proportion of morpho- and DNA types on and off the Louisiana shelf, May 2000. Overlaid is the profile of in situ chlorophyll fluorescence. The hatched bars indicate the sea floor. Station numbers are given in the left panel of each row, and stations are sorted from inshore to offshore. The lower row depicts profiles of in situ chlorophyll fluorescence (relative units) and salinity (\%) 
relation between microscopic and cytometric counts within this data set still shows the applicability of flow cytometry to quantify bacteria and shows that cell loss occurred independent of bacterial abundance in all samples. Average precision $\left(\mathrm{SD} \times \mathrm{mean}^{-1} \times 100\right)$ among triplicate cytometric measurements was $2.3 \%$ (range 0.3 to $5.3 \%$ ). The versatile utility of flow cytometry to quantify free-living, aquatic bacteria is, thus, confirmed by the present study. Cytometric quantification not is only substantially faster than epifluorescence microscopy but also provides more precise estimates due to the higher number of counted cells (Venrick 1978).

Bacterial abundances of up to 0.3 to $0.4 \times 10^{6}$ cells $\mathrm{ml}^{-1}$ and a sharp decline to $<0.1 \times 10^{6}$ cells ml ${ }^{-1}$ below the subsurface chlorophyll maximum (i.e., below $125 \mathrm{~m}$ ) in the open northwestern Gulf of Mexico and off the Louisiana shelf break outside the Mississippi River plume correspond to previous reports from the open Gulf of Mexico (Biddanda \& Benner 1997) and other oligotrophic oceans (Carlson et al. 1996 and references therein, Robarts et al. 1996, Jiao \& Ni 1997, Pedrós-Alió et al. 1999). Bacteria exhibited mostly population maxima in the upper half of the subsurface chlorophyll maximum, which is consistent with reports from other oceanic provinces (Li et al. 1992, Robarts et al. 1996, Pedrós-Alió et al. 1999). Bacterial distribution and production have been linked to phytoplankton as the major source of labile bacterial substrates through their production and exudation (e.g., Chin-Leo \& Benner 1992), and a direct relation of bacterial abundance to chlorophyll $a$ is widely accepted (see review in Gasol \& Duarte 2000). However, maximum primary production occurs within the upper half of the subsurface chlorophyll maximum (e.g., Jochem \& Zeitzschel 1993, Jochem et al. 1993). A vertical distribution of bacteria concomitant with primary production rates might be more expected in such systems than a mere match of chlorophyll distribution. Bacterial abundance showed little geographic variation in the open Gulf except for the shallow coastal station J6, which appears typical (Biddanda \& Benner 1997).

In addition, some stations in the open Gulf exhibited high surface abundance (J2, J4) or surface maxima (J1) of bacteria, which can be related to dense blooms of the filamentous cyanobacterium Trichodesmium sp. (Jochem \& Villareal unpubl. data). Surface blooms of Trichodesmium are widespread and abundant in the open Gulf (Biddanda \& Benner 1997) and account for $\leq 25 \%$ of total new nitrogen input in the north Pacific gyre (Karl et al. 1995, Letelier \& Karl 1996) and the tropical Atlantic Ocean (Carpenter et al. 1999). Nitrogen input from Trichodesmium may enhance the rate of heterotrophic utilization of DOM (Biddanda \& Benner 1997). Release of $\sim 25 \%$ of fixed nitrogen as amino acids (glutamate and glutamine; Capone et al. 1994) can also provide nutritious and labile dissolved organic substrate for bacterial production in surface waters. In the Baltic Sea, 5 to $10 \%$ of nitrogen fixed by diazotrophic, filamentous cyanobacteria were transferred into picoplankton cells (Ohlendieck et al. 2000).

Maximum abundance of $\sim 2 \times 10^{6}$ cells ml ${ }^{-1}$ in the Mississippi River plume in May 2000 are in the lower range of reports from this area (Chin-Leo \& Benner 1992, Amon \& Benner 1998, Pakulski et al. 2000) and may be related to the low river discharge and small extension of the plume. Substantially higher bacterial stocks were reported from the river flood in 1993 (up to $11.7 \times 10^{6}$ cells ml$^{-1}$; Amon \& Benner 1998). The high bacterial standing stocks and production within the plume have been linked to both riverine input of dissolved organic nitrogen and nutrients (Chin-Leo \& Benner 1992) and autochthonous production of DOM (Amon \& Benner 1998).

The highest bacterial abundance in the river mouth and a decrease along the salinity gradient contrast with earlier reports of maximum bacterial abundance and production at mid-salinities (10 to 20\%; Amon \& Benner 1998, Pakulski et al. 2000) related to highest phytoplankton stocks and production at mid-salinities (Lohrenz et al. 1990, Redalje et al. 1994, Gardner et al. 1997). In agreement with the present study, maximum bacterial abundance at low salinities near the river mouth was reported by Chin-Leo \& Benner (1992). Maximum bacterial production sometimes occurs further downstream the salinity gradient than maximum abundance (Chin-Leo \& Benner 1992, Pakulski et al. 2000). The nutrient load and amount of river discharge may influence the spatial distribution of bacterial abundance and production that peak further downstream during periods of high river discharge.

Although the introduction of epifluorescence microscopy enabled quantitative differentiation of bacterial morphotypes, only a few studies have reported such data. Mostly, differentiation of morphotypes and size classes of bacteria in microscopic counting is used only to convert bacterial numbers into carbon biomass more precisely. Quantitative data on bacterioplankton morphology are lacking for the Gulf of Mexico.

Simultaneous occurrence of cocci, rods, C-shaped bacteria and S-shaped bacteria in marine, epipelagic communities has been well documented (Sieburth 1979, Viles \& Sieracki 1992, Acinas et al. 1999). Despite the application of epifluorescence microscopy and scanning electron microscopy, most early studies reported only on coccoid and rod-shaped bacteria (e.g., Bowden 1977, Ferguson \& Rublee 1979, Fuhrman 1981, Palumbo et al. 1984). They did not mention curved bacteria, although these were already known as ubiquitous and abundant forms in oceanic waters (Sieburth 1979). Among curved bacteria, a smaller, 
strongly curved, aflagellate 'type A' was distinguished from a larger $\left(0.106 \mu \mathrm{m}^{3}\right)$, less curved, flagellate 'type $\mathrm{B}^{\prime}$ in the northeastern Atlantic and the western Baltic Sea (Rheinheimer \& Schmaljohann 1983, Schmaljohann 1984). Both forms appear similar (from Fig. 11 of Rheinheimer \& Schmaljohann 1983) to curved bacteria found in the present study. The horseshoe-shaped small form (type A) resembles Microcyclus marinus (syn. Flectobacillus marinus, Borrall \& Larkin 1978; syn. Cyclobacterium marinus, Raj \& Maloy 1990) as depicted in Sieburth (1979), which is abundant in oceanic waters (Sieburth 1979, Rheinheimer \& Schmaljohann 1983) and the Baltic Sea (Schmaljohann 1984). It may account for some of the genomic records of the Flexibacter-Cytophaga-Bacteroides group of bacteria in pelagic systems (e.g., Hagström et al. 2000).

Cell sizes and volumes reported from the northwestern Gulf of Mexico compare with reports from other marine systems (Bowden 1977, Rheinheimer \& Schmaljohann 1983, Ducklow 1986, Cho \& Azam 1990, Viles \& Sieracki 1992, Carlson et al. 1996, Pedrós-Alió et al. 1999) but are slightly lower than in coastal waters (Ferguson \& Rublee 1976, Fuhrman 1981, Palumbo et al. 1984). This result agrees with the general decrease in bacterial size from inshore to offshore waters (Palumbo et al. 1984). Digital bacteria sizing, however, was applied insufficiently to address such trends along the transects and in the Mississippi River plume. Slightly lower cell volumes than in previous studies might also result from DAPI staining, which sometimes leads to underestimation of cell size as compared with acridine orange staining because DAPI does not stain the cell wall (Suzuki et al. 1993).

Cocci were the dominant morphotype throughout the study. Their contribution to total bacteria (40 to $60 \%)$ was lower than previously reported (>50\%, Wiebe \& Pomeroy 1972; 80\%, Ferguson \& Rublee 1976) for pelagic systems but comparable with that in Arctic sea ice (Gradinger \& Zhang 1997). Early studies probably included phototrophic Prochlorococcus spp. and, sometimes, Synechococcus spp. in their counts of 'coccoid bacteria' (Schmaljohann 1984, Sieracki et al. 1995). Rods and curved bacteria showed similar contributions in the northwestern Gulf of Mexico but curved bacteria were more abundant than rods in the Mississippi River plume. The share of curved bacteria (water column average of 24 to $29 \%$ ) compares with their average contribution in the northeastern Atlantic $(19.2 \%$, Rheinheimer \& Schmaljohann 1983) and the Baltic Sea (24.4\%, Schmaljohann 1984). Robarts et al. (1996) report $13 \%$ of bacteria as rods and curved cells in the southeastern Mediterranean, and Jiao \& Ni (1997) a share of $\sim 10 \%$ for 'long-shaped cells' (rods and curved bacteria) in the western and central Pacific; both studies did not correct their cocci counts for
Prochlorococcus spp. abundance. In the present study, Prochlorococcus spp. would have overestimated cocci abundance derived from DAPI counts by $26 \%$ on average but up to $70 \%$ in surface samples, and total bacterial abundance by $13 \%$ on average but at times reaching up to $51 \%$, which corresponds to earlier reports (Campbell et al. 1994, Li et al. 1995, Sieracki et al. 1995).

Regional differences in the shares of bacterial morphotypes were less pronounced than changes with depth. Cocci tended to be less dominant toward the coast and within the chlorophyll subsurface maximum, where it is presumed that the supply of dissolved organic substrates is higher. This distribution of cocci might be explained by better adaptation to low organic substrate water due to their better surface-to-volume ratio as compared with rod-shaped and curved bacteria.

Whereas the shares of curved bacteria slightly increased inshore in the northwestern Gulf of Mexico, it increased along the salinity gradient in the Mississippi River plume. In the northeast Atlantic, the share of type A curved bacteria (cf. Microcyclus marinus) increased mostly toward the shore and with depth, whereas type B curved bacteria were more abundant offshore (Rheinheimer \& Schmaljohann 1983). However, in the Baltic Sea, the share of type A cells decreased with depth and during a bacterioplankton bloom following the phytoplankton spring bloom, whereas the contribution of type B cells increased 5 -fold during the bloom (Schmaljohann 1984). Schmaljohann (1984) concludes that type B are bacteria that respond rapidly to input of dissolved organic substrates whereas type A do not. Opposite regional trends in the shares of curved bacteria in the northwestern Gulf of Mexico and the Mississippi River plume might indicate different bacterial species. From the observed variety in cell sizes and shapes among curved bacteria, it is conceivable that this group concealed a variety of species and physiological types (Rheinheimer \& Schmaljohann 1983).

From this perception, it is not surprising that none of the distinguished morphotypes correlate with any distinguished DNA type. Whereas occasional flow sorting revealed a homogeneous composition of small cocci in the B-Ia subpopulation, it showed a diverse composition of B-IV, comprising rod-shaped cells of variable cell length, large C- and S-shaped bacteria, and brightly stained, large cocci. Each distinguished bacterial subgroup most likely conceals a variety of bacterial species that happen to exhibit a similar morphology or DNA content. Genomic analyses of bacterioplankton, in fact, confirm a much higher diversity than mirrored by the here-established morpho- and DNA types (e.g., Hagström et al. 2000). 
In all but the Mississippi River water samples, 4 clusters of bacteria could be distinguished by their apparent DNA content and cell size (light scatter). Subpopulation B-Ia and B-Ib are probably B-I bacteria as termed by Li et al. (1995) and Marie et al. (1997), but the distinction of B-Ia and B-Ib was apparent in all samples. B-III was distinguished by higher apparent DNA content but similar light scatter compared with B-Ib and was also reported by Marie et al. (1997) and Casotti et al. (2000), but not by Li et al. (1995). In some of Li et al.'s (1995) growth experiments, their B-II (similar DNA content but smaller light scatter as compared with their B-I) split, however, into 2 subpopulations exhibiting similar DNA content but different light scatter, which they termed 'B-IIa' and 'B-IIb'; in fact, B-IIb appears very similar to the B-III population reported by Marie et al. (1997), Casotti et al. (2000) and the present study. B-II bacteria with higher apparent DNA content but smaller light scatter signature than B-I bacteria (Li et al. 1995, Marie et al. 1997, Gasol \& del Giorgio 2000) were not detected in the Gulf of Mexico.

It might be disputed whether the observed differences in DNA fluorescence reflect different groups of bacteria or different stain penetration due to dye characteristics and the physiological state of the populations ( $\mathrm{Li}$ et al. 1995). Similar DNA types of bacteria could be, however, distinguished by a variety of DNA dyes, including a suite of new cyanine dyes as well as DAPI, and from a variety of marine and freshwater systems ranging from oligotrophic high-mountain lakes to eutrophic reservoirs and from estuaries to open oceans (Gasol \& del Giorgio 2000). The presence of varying shares of bacteria characterized by their different DNA content seems to be a ubiquitous, natural phenomenon with ecological meaning rather than a preparation artifact (Marie et al. 1997).

B-Ia bacteria were the most abundant DNA type (average of $46 \%$, range 26 to $60 \%$ ) and dominated the euphotic zone. Their share decreased below the subsurface chlorophyll maximum, whereas that of B-Ib bacteria (10 to $20 \%$ ) remained fairly constant throughout the upper $200 \mathrm{~m}$ water column. This distinct vertical distribution of B-Ia and B-Ib further justifies their separation into different DNA types. B-I bacteria were reported to be more adapted to oligotrophic conditions and to exhibit decreasing shares toward the coast and riverine nutrient inputs ( $\mathrm{Li}$ et al. 1995, Casotti et al. 2000). Whereas their dominance in Gulf of Mexico surface waters complies with these reports, regional trends in the open Gulf or within the Mississippi River plume were not discernible.

With an average of $32 \%$ (range 22 to $55 \%$ ), B-III bacteria were the second-most abundant DNA type and dominated the bacterioplankton below the euphotic zone. In the English Channel, B-III was reported as the most abundant population, although the authors gave no numerical information (Marie et al. 1997), and in the central Mediterranean, B-III became dominant toward the coast where riverine nutrient inputs were expected (Casotti et al. 2000). This subpopulation was not found, however, in the western Mediterranean and the equatorial Pacific (Marie et al. 1997).

Although little work has been performed to characterize the different DNA types of bacteria taxonomically and physiologically (Gasol \& del Giorgio 2000), several studies revealed that high-DNA bacterial clusters exhibit a higher growth rate or cell-specific activity (Li et al. 1995, Jellett et al. 1996, Gasol et al. 1999, Servais et al. 1999, Troussellier et al. 1999, Yamada et al. 2000) and are more prone to protozoan grazing (Gasol et al. 1999). The latter result is consistent with the reported size- and activity-selective grazing behavior of flagellates (Jürgens \& Güde 1994, del Giorgio et al. 1996, López-Amorós et al. 1998). The share of B-III ('high DNA') bacteria shall, therefore, correspond to that of 'active' bacteria as derived from the Live/ Dead fluorescence kit (Molecular Probes), autoradiography and rRNA probes (Gasol \& del Giorgio 2000). On the other hand, low growth rates in incubation experiments (Li et al. 1995, Gasol et al. 1999) led Gasol et al. (1999) to regard a large part of B-I bacteria ('low DNA cells', in their term) as dead or inactive, contributing to the significant number of inactive bacteria often found in the oceans (Gasol \& del Giorgio 2000).

From the distinct and recurrent vertical distribution of low-DNA B-Ia bacteria with significantly decreasing shares below the euphotic zone at all sampled stations, it remains unclear, however, why the share of dead or inactive bacteria should decrease below the zone of primary production. If B-III bacteria ('high DNA cells' sensu Gasol et al. 1999) are active cells, why would their contribution to bacterioplankton decrease toward the productive layer where they are likely to encounter higher and more frequent substrate inputs by phytoplankton exudation? In the concept of Gasol et al. (1999), the vertical distribution reported here of active (B-III) and 'inactive/dormant/dead' (B-I) cells would point toward a strong, community-shaping impact of bacteria grazers: despite their higher growth rates, B-III bacteria would be top-down controlled by their grazers, whereas the less active B-I bacteria escape grazing pressure and remain abundant without fast or any growth. It is only below the euphotic zone, where the abundance of heterotrophic flagellates and ciliates, and thus their grazing pressure, decreases, that active B-III bacteria can gain a higher contribution to bacterioplankton by their faster than B-I growth.

The interpretation of low-DNA bacteria being dead or inactive cells relies, however, on separate preparations and techniques (cytometry for DNA types, micro- 
scopy for dead/live distinction), and the similarity of average shares of low-DNA and inactive bacteria to total bacterial counts in some but not all experiments (Gasol et al. 1999). Direct proof, for example by dual DNA- and dead/live-labeling and flow cytometry, that all low-DNA bacteria are inactive and all high-DNA bacteria are active is lacking, and the correspondence of the contribution of low-DNA and inactive bacteria to total bacterial counts may be circumstantial. Flow sorting of Gulf of Mexico samples revealed that at least B-Ia (small cocci) and B-IV (rods, curved bacteria, large cocci) DNA types differ in morphology and species composition. Higher cell-specific uptake rates of ${ }^{3} \mathrm{H}$-thymidine (Jellett et al. 1996) and leucine (Servais et al. 1999) of high-DNA bacteria might be seen in the context that bacteria with a 5-fold higher DNA content (Gasol \& del Giorgio 2000) also need to incorporate 5 times as much thymidine for a single DNA replication. Still, the higher cell-specific growth rates of high-DNA cells in incubation experiments (Li et al. 1995, Gasol et al. 1999) leave grazer impact as an important, community-shaping process (Jürgens \& Güde 1994) that deserves further investigation.

It is also conceivable that the distinguished DNA types conceal consortia of bacteria with different physiological adaptation and abilities rather than active/ inactive differences. Persistent vertical zonation of bacteria was also documented by genetic studies: The predominance of $\alpha$-Proteobacteria clones in surface waters has been described repeatedly (Field et al. 1997, Rappé et al. 1997, Acinas et al. 1999). In the western Mediterranean, the abundance of SAR11 A-1 and A-2 clusters of $\alpha$-Proteobacteria decreased sharply below the subsurface chlorophyll maximum, whereas cluster SAR11 G1 and $\gamma$-Proteobacteria increased (Acinas et al. 1999).

Since some of the newly marketed cyanine dyes, particularly SYBR Green II, are suited for live bacterial DNA staining in seawater (Lebaron et al. 1998), flow sorting of stained cells might provide a tool for subpopulation characterization. Further insight might be gained by combining cytometric quantification of bacteria by DNA staining with fluorescent molecular probes specific for bacterial subclasses or species (e.g., Völsch et al. 1990, Porter et al. 1996). Despite the advantage of relatively easy and fast sample preparation with SYBR Green I, its broad emission spectrum might be bothersome, and a green fluorescent DNA dye with a narrow emission spectrum may prove more useful in such attempts. Numerous molecular probes await further improvement in staining protocols and instrumentation to increase the signal-to-noise ratio for routine application in field studies (Collier \& Campbell 1999) but provide an exciting outlook into the study of bacterioplankton diversity in situ.
Acknowledgements. I thank captain Cantu and the crew of RV 'Longhorn' for their assistance at sea. Mark McCarthy provided nutrient analyses. I am grateful to Ron Benner for the opportunity to participate in the March 2000 cruise to the Mississippi River plume, which was supported by grant OCE 9730223. This research was funded by the Nancy Lee and Perry Bass Endowment to Wayne S. Gardner, The University of Texas at Austin Marine Science Institute. This is UTMSI Contribution No. 1186.

\section{LITERATURE CITED}

Acinas SG, Antón J, Rodgríguez-Valera F (1999) Diversity of free-living and attached bacteria in offshore western Mediterranean waters as depicted by analysis of genes encoding 16S rRNA. Appl Environ Microbiol 65:514-522

Amon RMW, Benner R (1998) Seasonal patterns of bacterial abundance and production in the Mississippi River plume and their importance for the fate of enhanced primary production. Microb Ecol 35:289-300

Biddanda B, Benner R (1997) Major contribution from mesopelagic plankton to heterotrophic metabolism in the upper ocean. Deep-Sea Res 44:2069-2085

Borrall R, Larkin JM (1978) Flectobacillus marinus (Raj) comb. nov., a marine bacterium previously assigned to Microcyclus. Int J Syst Bacteriol 28:341-343

Bowden WB (1977) Comparison of two direct-count techniques for enumerating aquatic bacteria. Appl Environ Microbiol 33:1229-1232

Campbell L, Nolla HA, Vaulot D (1994) The importance of Prochlorococcus to community structure in the central north Pacific Ocean. Limnol Oceanogr 39:954-961

Capone DG, Ferrier MD, Carpenter EJ (1994) Amino-acid cycling in colonies of the planktonic marine cyanobacterium Trichodesmium thiebautii. Appl Environ Microbiol 60:3989-3995

Carlson CA, Ducklow HW, Sleeter TD (1996) Stocks and dynamics of bacterioplankton in the northwestern Sargasso Sea. Deep-Sea Res II 43:491-515

Carpenter EJ, Montoya JP, Burns J, Mulholland MR, Subramaniam A, Capone DG (1999) Extensive bloom of a $\mathrm{N}_{2}$ fixing diatom/cyanobacterial association in the tropical Atlantic Ocean. Mar Ecol Prog Ser 185:273-283

Casotti R, Brunet C, Aronne B, Ribera d'Alcala M (2000) Mesoscale features of phytoplankton and planktonic bacteria in a coastal area as induced by external water masses. Mar Ecol Prog Ser 195:15-27

Chin-Leo G, Benner R (1992) Enhanced bacterioplankton production and respiration at intermediate salinities in the Mississippi River plume. Mar Ecol Prog Ser 87:87-103

Cho BC, Azam F (1990) Biogeochemical significance of bacterial biomass in the ocean's euphotic zone. Mar Ecol Prog Ser 63:253-259

Collier JL, Campbell L (1999) Flow cytometry in molecular aquatic ecology. Hydrobiologia 401:33-53

del Giorgio PA, Gasol JM, Vaque D, Mura P, Augusti S, Duarte CM (1996) Bacterioplankton community structure: protists control net production and the proportion of active bacteria in a coastal marine community. Limnol Oceanogr 41:1169-1179

Ducklow HW (1986) Bacterial biomass in warm-core Gulf Stream ring 82-B: mesoscale distributions, temporal changes and production. Deep-Sea Res 33:1789-1812

Ferguson RL, Rublee P (1976) Contribution of bacteria to standing crop of coastal plankton. Limnol Oceanogr 21: 141-145 
Field KG, Gordon D, Wright T, Rappé M, Urbach E, Vergin K, Giovannoni SJ (1997) Diversity and depth-specific distribution of SAR11 cluster rRNA genes from marine planktonic bacteria. Appl Environ Microbiol 63:63-70

Fuhrman JA (1981) Influence of method on the apparent size distribution of bacterioplankton cells: epifluorescence microscopy compared to scanning electron microscopy. Mar Ecol Prog Ser 5:103-106

Gardner WS, Cavaletto JF, Cotner JB, Johnson JR (1997) Effects of natural light on nitrogen cycling rates in the Mississippi River plume. Limnol Oceanogr 42:273-281

Gasol JM, del Giorgio PA (2000) Using flow cytometry for counting natural planktonic bacteria and understanding the structure of planktonic bacterial communities. Sci Mar 64:197-224

Gasol JM, Duarte CM (2000) Comparative analyses in aquatic microbial ecology: how far do they go? FEMS Microbiol Ecol 31:99-106

Gasol JM, Morán XAG (1999) Effects of filtration on bacterial activity and picoplankton community structure as assessed by flow cytometry. Aquat Microb Ecol 16:251-264

Gasol JM, Zweifel UL, Peters F, Fuhrman JA, Hagström ^ (1999) Significance of size and nucleic acid content heterogeneity as measured by flow cytometry in natural planktonic bacteria. Appl Environ Microbiol 65:4475-4483

Gradinger R, Zhang Q (1997) Vertical distribution of bacteria in Arctic sea ice from the Barents and Laptev Seas. Polar Biol 17:448-454

Hagström ^̊, Pinhassi J, Zweifel UL (2000) Biogeographical diversity among marine bacterioplankton. Aquat Microb Ecol 21:231-244

Jellett JF, Li WKW, Dickie PM, Boraie A, Kepkay PE (1996) Metabolic activity of bacterioplankton communities assessed by flow cytometry and single carbon substrate utilization. Mar Ecol Prog Ser 136:213-225

Jiao NZ, Ni IH (1997) Spatial variation of size-fractionated chlorophyll, cyanobacteria and heterotrophic bacteria in the central and western Pacific. Hydrobiologia 352: 219-230

Jochem FJ (1995) Phototrophic picoplankton community structure in three different pelagic regimes in the Arabian Sea. Mar Ecol Prog Ser 117:307-314

Jochem FJ Meyerdierks D (1999) Simultaneous cytometric measurement of DNA cell cycle and cellular chlorophyll in marine eukaryotic phytoplankton. Mar Ecol Prog Ser 185: 301-307

Jochem FJ, Zeitzschel B (1993) Productivity regime and phytoplankton size structure in the tropical and subtropical North Atlantic in spring 1989. Deep-Sea Res II 40: 495-519

Jochem FJ, Pollehne F, Zeitzschel B (1993) Productivity regime and phytoplankton size structure in the Arabian Sea. Deep-Sea Res II 40:711-735

Jürgens K, Güde H (1994) The potential importance of grazing-resistant bacteria in planktonic systems: a review. Mar Ecol Prog Ser 112:169-188

Karl DM, Letelier R, Hebel D, Tupas L, Dore J, Christian J, Winn C (1995) Ecosystem changes in the north Pacific subtropical gyre attributed to the 1991-1992 El Niño. Nature 373:230-234

Lebaron P, Parthuisot N, Catala P (1998) Comparison of blue nucleic acid dyes for flow cytometric enumeration of bacteria in aquatic systems. Appl Environ Microbiol 64: 1725-1730

Letelier RM, Karl DM (1996) Role of Trichodesmium sp. in the productivity of the subtropical North Pacific Ocean. Mar Ecol Prog Ser 133:263-273
Li WKW (1994) Primary production of prochlorophytes, cyanobacteria, and eucaryotic ultraphytoplankton: measurements from flow cytometric sorting. Limnol Oceanogr 39: 169-175

Li WKW, Dickie PM, Irwin BD, Wood AM (1992) Biomass of bacteria, cyanobacteria, prochlorophytes and photosynthetic eukaryotes in the Sargasso Sea. Deep-Sea Res Part I 39:501-519

Li WKW, Jellett JF, Dickie PM (1995) DNA distributions in planktonic bacteria stained with TOTO or TO-PRO. Limnol Oceanogr 40:1485-1495

Lohrenz SE, Dagg MJ, Whitledge TE (1990) Enhanced primary production at the plume/oceanic interface of the Mississippi River. Cont Shelf Res 10:639-664

López-Amorós R, Comas J, García MT, Vives-Rego J (1998) Use of the 5-cyano-2,3-ditolyl tetrazoliumchloride reduction test to assess respiring marine bacteria and grazing effects by flow cytometry during linear alkylbenzene sulfonate degradation. FEMS Microbiol Ecol 27:33-42

Marie D, Partensky F, Jacquet S, Vaulot D (1997) Enumeration and cell cycle analysis of natural populations of marine picoplankton by flow cytometry using the nucleic acid stain SYBR Green I. Appl Environ Microbiol 63: 186-193

Noble RT, Fuhrman JA (1998) Use of SYBR Green I for rapid epifluorescence counts of marine viruses and bacteria. Aquat Microb Ecol 14:113-118

Ohlendieck U, Stuhr A, Siegmund H (2000) Nitrogen fixation by diazotrophic cyanobacteria in the Baltic Sea and transfer of the newly fixed nitrogen to picoplankton organisms. J Mar Syst 25:213-219

Pakulski JD, Benner R, Whitledge T, Amon R, Eadie B, Cifuentes L, Ammerman J, Stockwell D (2000) Microbial metabolism and nutrient cycling in the Mississippi and Atchafalaya River plumes. Estuar Coast Shelf Sci 50: 173-184

Palumbo AV, Ferguson RL, Rublee PA (1984) Size of suspended bacterial cells and association of heterotrophic activity with size fractions of particles in estuarine and coastal waters. Appl Environ Microbiol 48:157-164

Pedrós-Alió C, Calderón-Paz JI, Guixa-Boixereu N, Estrada M, Gasol JM (1999) Bacterioplankton and phytoplankton biomass and production during summer stratification in the northwestern Mediterranean Sea. Deep-Sea Res I 46: 985-1019

Porter J, Deere D, Pickup R, Edwards C (1996) Fluorescent probes and flow cytometry: new insights into environmental bacteriology. Cytometry 23:91-96

Raj HD, Maloy SR (1990) Proposal of Cyclobacterium marinus gen. nov., comb. nov. for a marine bacterium previously assigned to the genus Flectobacillus. Int J Syst Bacteriol 40:337-347

Rappé MS, Kemp PF, Giovannoni SJ (1997) Phylogenetic diversity of marine coastal picoplankton 16S rRNA genes cloned from the continental shelf off Cape Hatteras, North Carolina. Limnol Oceanogr 42:811-826

Redalje D, Lohrenz SE, Fahnenstiel G (1994) The relationship between primary production and vertical export of particulate organic matter in a river impacted coastal ecosystem. Estuaries 17:829-838

Rheinheimer G, Schmaljohann R (1983) Investigations on the influence of coastal upwelling and polluted rivers on the microflora of the northeastern Atlantic off Portugal-I. Size and composition of the bacterial population. Bot Mar 26:137-152

Robarts RD, Zohary T, Waiser MJ, Yacobi YZ (1996) Bacterial abundance, biomass, and production in relation to phyto- 
plankton biomass in the Levantine Basin of the southeastern Mediterranean Sea. Mar Ecol Prog Ser 137:273-281

Schmaljohann R (1984) Morphological investigations on bacterioplankton of the Baltic Sea, Kattegat and Skagerrak. Bot Mar 27:425-436

Servais P, Courties C, Lebaron P, Troussellier M (1999) Coupling bacterial activity measurements with cell sorting by flow cytometry. Microb Ecol 38:180-189

Sieburth JMcN (1979) Sea microbes. Oxford University Press, New York

Sieracki ME, Haugen EM, Cucci TL (1995) Overestimation of heterotrophic bacteria in the Sargasso Sea: direct evidence by flow and imaging cytometry. Deep-Sea Res 42: 1399-1409

Suzuki MT, Sherr EB, Sherr BF (1993) DAPI direct counting underestimates bacterial abundances and average cell size compared to AO direct counting. Limnol Oceanogr 38:1566-1569

Troussellier M, Courties C, Zettelmaier S (1995) Flow cytometric analysis of coastal lagoon bacterioplankton and picophytoplankton: fixation and storage effects. Estuar Coast Shelf Sci 40:621-633

Troussellier M, Courties C, Lebaron P, Servais P (1999) Flow cytometric discrimination of bacterial populations in sea-

Editorial responsibility: John Dolan, Villefranche-sur-Mer, France water based on SYTO 13 staining of nucleic acids. FEMS Microbiol Ecol 29:319-330

Turley CM, Hughes DJ (1992) Effects of storage on direct estimates of bacterial numbers of preserved seawater samples. Deep-Sea Res 39:375-394

Venrick EL (1978) How many cells to count? In: Sournia A (ed) Phytoplankton manual. Monographs on oceanographic methodology 6. UNESCO, Paris, p 167-180

Viles CL, Sieracki ME (1992) Measurement of marine picoplankton cell size by using a cooled, charge-coupled device camera with image-analyzed fluorescence microscopy. Appl Environ Microbiol 58:584-592

Völsch A, Nader WF, Geiss HK, Nebe G, Birr C (1990) Detection and analysis of two serotypes of ammonia-oxidizing bacteria in sewage plants by flow cytometry. Appl Environ Microbiol 56:2430-2435

Wiebe WJ, Pomeroy LR (1972) Microorganisms and their association with aggregates and detritus in the sea: a microscopic study. Mem Ist Ital Idrobiol 29(Suppl): 325-342

Yanada M, Yokokawa T, Lee CW, Tanaka H, Kudo I, Maita Y (2000) Seasonal variation of two different heterotrophic bacterial assemblages in subarctic coastal seawater. Mar Ecol Prog Ser 204:289-292

Submitted: November 17, 2000; Accepted: May 11, 2001 Proofs received from author(s): August 13, 2001 